\title{
KINERJA KARYAWAN: KOMPENSASI DAN PROMOSI
}

\author{
JABATAN \\ Sri Langgeng Ratnasari \\ Postgraduate Program \\ Riau Kepulauan University \\ Jl. Batu Aji Baru No. 55, Batu Aji, Batam 29432, Indonesia \\ E-mail: sarisucahyo@yahoo.com
}

\begin{abstract}
Employee performance is one of the most important factors in an organization, because employee performance is crucial in determining organizational performance. This study aims to determine the effect of compensation on employee performance, the effect of job promotions on employee performance, and the effect of compensation and job promotions on employee performance. This research is a descriptive study through a quantitative approach. The population of this research is the employees of PT. MSP Batam as many as 50 employees. The sampling technique uses census techniques, so the number of samples is 50 employees. The results of testing partially the effect of compensation on employee performance is significant, the effect of job promotions on employee performance has a significant effect, and simultaneously the effect of compensation and job promotions on employee performance has no significant effect.
\end{abstract}

Keywords; Employee Performance, Compensation, Job Promotion

\begin{abstract}
Abstrak
Kinerja karyawan merupakan salah satu faktor yang sangat penting dalam organisasi, karena dengan kinerja karyawan sangat menentukan kinerja organisasi. Penelitian ini memiliki tujuan untuk mengetahui pengaruh kompensasi terhadap kinerja karyawan, pengaruh promosi jabatan terhadap kinerja karyawan, dan pengaruh kompensasi dan promosi jabatan terhadap kinerja karyawan. Penelitian ini merupakan penelitian deskriptif melalui pendekatan kuantitatif. Populasi penelitian ini adalah karyawan bagian produksi PT. MSP Batam sebanyak 50 karyawan. Teknik pengambilan sampel menggunakan teknik sensus, sehingga jumlah sampelnya adalah 50 karyawan. Hasil pengujian secara parsial pengaruh kompensasi terhadap kinerja karyawan adalah signifikan, pengaruh promosi jabatan terhadap kinerja karyawan berpengaruh signifikan, dan secara simultan pengaruh kompensasi dan promosi jabatan terhadap kinerja karyawan berpengaruh tidak signifikan.
\end{abstract}

Kata kunci: Kinerja Karyawan, Kompensasi, Promosi Jabatan 


\section{PENDAHULUAN}

Kinerja karyawan merupakan salah satu faktor yang menjadi perhatian utama setiap organisasi, hal ini dikarenakan akumulasi dari kinerja karyawan secara keseluruhan merupakan kinerja organisasi. PT. MSP merupakan perusahaan kontraktor yang beralamat di Panbil Commercial Area, Mukakuning Kota Batam 29433. Perusahaan ini memiliki 50 karyawan bagian produksi.

Berdasarkan observasi, informasi dan data kualitatif diindikasikan bahwa Kompensasi yang diberikan perusahaan dirasakan belum sesuai dengan yang diharapkan karyawan. Hal ini diketahui dari hasil wawancara pada karyawan perusahaan. Promosi jabatan dirasakan masih didasarkan rasa suka atasan pada staffnya, belum berdasarkan kinerja. Hal ini diketahui dari informasi karyawan yang bekerja di perusahaan ini.

Melihat fenomena tersebut, maka perlu dilakukan penelitian dengan judul Kinerja Karyawan: Kompensasi Dan Promosi Jabatan. Hal ini dilakukan untuk memberikan masukan kepada manajemen dari hasil penelitian ini untuk dapat digunakan sebagai bahan pengambilan keputusan.

\section{Perumusan Masalah}

Berdasarkan latar belakang yang telah dipaparkan, maka dapat dirumuskan masalah penelitian sebagai berikut:

1. Apakah kompensasi berpengaruh terhadap kinerja karyawan?

2. Apakah promosi jabatan berpengaruh terhadap kinerja karyawan?

3. Apakah kompensasi dan promosi jabatan secara simultan berpengaruh terhadap kinerja karyawan?

\section{Hipotesis Penelitian}

Hipotesis penelitian ini dapat disusun sebagai berikut:

$\mathrm{H}_{1}$ :Kompensasi berpengaruh terhadap kinerja karyawan.

$\mathrm{H}_{2}$ :Promosi Jabatan berpengaruh terhadap kinerja karyawan.

$\mathrm{H}_{3}$ :Kompensasi dan Promosi Jabatan berpengaruh terhadap kinerja karyawan.

\section{KERANGKA TEORI DAN PENGEMBANGAN HIPOTESIS}

\section{Kinerja Karyawan}

Menurut Fahmi (2015) kinerja karyawan adalah hasil kerja yang diperoleh karyawan dalam satuan waktu tertentu. Sutrisno (2016) menyatakan bahwa "kinerja karyawan adalah hasil kerja karyawan apabila dilihat dari aspek kualitas, kuantitas, waktu kerja dan kerja sama untuk mencapai tujuan yang sudah ditetapkan organisasi”.

Sinambela (2016) menyatakan bahwa kinerja merupakan kemampuan pegawai dalam melakukan sesuatu keahlian tertentu. Kemampuan dan motivasi saling menentukan satu sama lain, salah satunya adalah kinerja. Hal ini berarti bahwa setinggi apapun tingkat kemampuan karyawan tidak akan menghasilkan kinerja yang optimal apabila dikerjakan dengan motivasi rendah, demikian juga sebaliknya.

Bangun (2015) menjelaskan bahwa kinerja merupakan hal yang diinginkan baik dari pihak pemberi kerja maupun para pekerja. Pemberi kerja menginginkan kinerja karyawannya baik untuk kepentingan peningkatan hasil kerja dan keuntungan perusahaan. Disisi lain, para pekerja berkepentingan untuk pengembangan diri dan promosi pada pekerjaannya. Secara umum, dapat dikatakan bahwa kinerja karyawan yang baik bertujuan untuk meningkatkan produktivitas. Oleh karena itu, perbaikan 
Sri Langgeng Ratnasari, Kinerja Karyawan:Kompensasi \& Promosi Jabatan...

sistem kerja dilakukan oleh setiap komponen yang ada dalam perusahaan. Untuk tujuan tersebut akan dibutuhkan sistem manajemen kinerja yang baik.

Bangun (2015) mendefinisikan "Kinerja adalah hasil pekerjaan yang dicapai seseorang berdasarkan persyaratan-persyaratan pekerjaan. Suatu pekerjaan mempunyai persyaratan tertentu untuk dapat dilakukan dalam mencapai tujuan yang disebut juga sebagai standar pekerjaan".

Leonardo dan Fransisca menyatakan bahwa kinerja adalah kuantitas dan kualitas kerja individu atau sekelompok karyawan dalam melaksanakan tugas pokok dan fungsinya.

Menurut Wibowo (2016) menyatakan "kinerja berasal dari pengertian performance, ada pula yang memberikan pengertian performance sebagai hasil kerja tetapi juga termasuk bagaimana proses pekerjaan berlangsung".

Berdasarkan definisi kinerja karyawan yang diurakan oleh beberapa ahli, maka dapat disimuplkan bahwa kinerja merupakan hasil kerja baik secara kuantitas dan kualitas dari pekerjaan yang dihasilkan.

\section{Kompensasi}

Kompensasi adalah semua jenis penghargaan yang berupa uang atau bukan uang yang diberikan kepada karyawan secara layak dan adil atas jasa mereka dalam mencapai tujuan perusahaan, Sutrisno (2015).

Sunyoto (2015) menyatakan bahwa kompensasi adalah segala sesuatu yang diterima oleh pekerja sebagai balas jasa atas kerja mereka.

Menurut Sutrisno (2015) mengemukakan bahwa kompensasi dapat didefiniskan sebagai bentuk penghargaan yang diberikan pada karyawan sebagai balas jasa atas kontribusi yang mereka berikan pada organisasi.
Berdasarkan definisi-definisi beberapa ahli di atas maka dapat disimpulkan bahwa kompensasi adalah balas jasa dari organisasi kepada karyawan atas hasil kerjanya, baik berupa uang maupun uang.

\section{Promosi Jabatan}

Promosi jabatan menurut Hasibuan (2016) adalah perpindahan yang memperbesar authority dan responsibility karyawan ke jabatan yang lebih tinggi di dalam satu organisasi sehingga kewajiban, hak, status, dan penghasilannya semakin bertambah besar. Dengan adanya promosi jabatan, karyawan merasa dihargai, diperhatikan, dibutuhkan, dan diakui kemampuan kerjanya oleh perusahaan, sehingga mereka dapat menghasilkan output yang tinggi dan memperkuat loyalitas pada organisasi.

Fahmi (2016) promosi jabatan adalah suatu kenaikan pada posisi yang lebih tinggi. Promosi tersebut bisa berupa kenaikan jabatan dari rendah ke posisi yang lebih tinggi. Berdasarkan definisi-definisi di atas maka dapat disimpulkan bahwa definisi promosi jabatan adalah pemberian penghargaan atas hasil kerja karyawan berupa kenaikan jabatan.

\section{METODE PENELITIAN}

\section{Objek Penelitian}

Objek penelitian ini adalah karyawan bagian produksi PT. MSP.

\section{Subjek Penelitian}

Subjek dalam penelitian ini adalah karyawan bagian produksi PT. MSP yang berjumlah 50 orang.

\section{Populasi}

Populasi adalah generalisasi yang terdiri atas objek atau subjek yang mempunyai kualitas dan karakteristik tertentu yang ditetapkan untuk dipelajari dan kemudian ditarik kesimpulannya. Populasi penelitian ini adalah seluruh karyawan bagian produksi PT. 
MKP yang berjumlah 50 karyawan.

\section{Sampel}

Teknik pengambilan sampel pada penelitian ini menggunakan teknik Non probability yaitu sampel jenuh atau sering disebut total sampling. Menurut Sugiyono (2015) sampel jenuh yaitu teknik penentuan sampel dengan cara mengambil seluruh anggota populasi sebagai responden atau sampel, sehingga sampel dalam penelitian ini adalah seluruh karyawan PT. MKP sebanyak 50 karyawan.

\section{Teknik Analisis Data}

Teknik analisis data pada penelitian menggunakan regresi linear berganda dengan program SPSS.

\section{Koefisien Korelasi $(R)$}

Analisis koefisien korelasi $(\mathrm{R})$ digunakan untuk mengukur keeratan hubungan antara variabel bebas $(\mathrm{X})$ terhadap variabel terikat (Y), dalam hal ini mengukur kuat lemahnya hubungan Kompensasi (X1), dan Promosi Jabatan (X2) dengan Kinerja Karyawan (Y). Nilai koefesien korelasi menurut Sugiyono (2015) memiliki nilai yang berkisar antara -1 sampai +1 , dimana kriteria pemanfaatnya dijelaskan berikut ini:

1. Jika nilai $r>0$, artinya tejadi hubungan yang linier positif, yaitu makin besar variabel $\mathrm{X}$ maka semakin besar variabel Y.

2. Jika nilai $r<0$, artinya terjadi hubungan yang linier negatif, yaitu semakin kecil nilai variabel $\mathrm{X}$ maka semakin besar variabel Y atau sebaliknya semakin besar variabel $\mathrm{X}$ maka semakin kecil variabel Y.

3. Jika nilai $\mathrm{r}=0$, artinya tidak ada hubungan antara variabel $\mathrm{X}$ dengan variabel Y. Jika nilai $r=1$ atau $=-1$, terjadi hubungan linier sempurna, yaitu berupa garis lurus, sedangkan bagi r yang mengarah kearah angka 0 maka garis semakin tidak lurus.

\section{Koefisien Determinasi $\left(R^{2}\right)$}

Koefisien determinasi berfungsi untuk mengetahui persentase besarnya pengaruh variabel independen dan variabel dependen. Pada penggunaannya, koefisien determinasi ini dinyatakan dalam persentase $(\%)$ dengan rumus berikut:

$K d=r^{2} \times 100 \%$

Keterangan :

$\mathrm{Kd}=$ Koefisien determinasi

$\mathrm{r} \quad=$ Koefisien korelasi yang dikuadratkan

Pengujian Hipotesis

Uji Validitas dan Reliabilitas

Tabel 1 Uji Validitas Kompensasi

\begin{tabular}{lllll}
\hline No & Item & r hitung & r tabel & Keterangan \\
\hline 1 & $\mathrm{X} 1.1$ & 0.846 & 0.2816 & Valid \\
2 & $\mathrm{X} 1.2$ & 0.753 & 0.2816 & Valid \\
3 & $\mathrm{X} 1.3$ & 0.581 & 0.2816 & Valid \\
4 & $\mathrm{X} 1.4$ & 0.677 & 0.2816 & Valid \\
5 & $\mathrm{X} 1.5$ & 0.684 & 0.2816 & Valid \\
6 & $\mathrm{X} 1.6$ & 0.584 & 0.2816 & Valid \\
7 & $\mathrm{X} 1.7$ & 0.649 & 0.2816 & Valid \\
8 & $\mathrm{X} 1.8$ & 0.729 & 0.2816 & Valid \\
9 & $\mathrm{X} 1.9$ & 0.594 & 0.2816 & Valid \\
10 & X1.10 & 0.693 & 0.2816 & Valid \\
11 & X1.11 & 0.766 & 0.2816 & Valid \\
12 & X1.12 & 0.846 & 0.2816 & Valid \\
13 & X1.13 & 0.689 & 0.2816 & Valid \\
14 & X1.14 & 0.516 & 0.2816 & Valid \\
15 & X1.15 & 0.766 & 0.2816 & Valid \\
16 & X1.16 & 0.557 & 0.2816 & Valid \\
\hline
\end{tabular}

Sumber: Hasil Olahan Data, 2019

Tabel 2 Uji Validitas Promosi Jabatan

\begin{tabular}{ccccc}
\hline No & Item & r hitung & r tabel & Keterangan \\
\hline 1 & X2.1 & 0.350 & 0.2816 & Valid \\
2 & X2.2 & 0.562 & 0.2816 & Valid \\
3 & X2.3 & 0.615 & 0.2816 & Valid \\
4 & X2.4 & 0.766 & 0.2816 & Valid \\
5 & X2.5 & 0.708 & 0.2816 & Valid \\
6 & X2.6 & 0.815 & 0.2816 & Valid \\
7 & X2.7 & 0.733 & 0.2816 & Valid \\
8 & X2.8 & 0.389 & 0.2816 & Valid \\
9 & X2.9 & 0.571 & 0.2816 & Valid \\
10 & X2.10 & 0.745 & 0.2816 & Valid \\
11 & X2.11 & 0.815 & 0.2816 & Valid \\
12 & X2.12 & 0.766 & 0.2816 & Valid \\
13 & X2.13 & 0.652 & 0.2816 & Valid \\
14 & X2.14 & 0.815 & 0.2816 & Valid \\
15 & X2.15 & 0.732 & 0.2816 & Valid \\
\hline
\end{tabular}

Sumber: Hasil Olahan Data, 2019 
Sri Langgeng Ratnasari, Kinerja Karyawan:Kompensasi \& Promosi Jabatan...

Tabel 3 Uji Validitas Kinerja Karyawan

\begin{tabular}{lllll}
\hline No & Item & r hitung & r tabel & Keterangan \\
\hline 1 & Y1.1 & 0.712 & 0.2816 & Valid \\
2 & Y1.2 & 0.716 & 0.2816 & Valid \\
3 & Y1.3 & 0.682 & 0.2816 & Valid \\
4 & Y1.4 & 0.744 & 0.2816 & Valid \\
5 & Y1.5 & 0.683 & 0.2816 & Valid \\
6 & Y1.6 & 0.604 & 0.2816 & Valid \\
7 & Y1.7 & 0.658 & 0.2816 & Valid \\
8 & Y1.8 & 0.638 & 0.2816 & Valid \\
9 & Y1.9 & 0.682 & 0.2816 & Valid \\
10 & Y1.10 & 0.744 & 0.2816 & Valid \\
11 & Y1.11 & 0.683 & 0.2816 & Valid \\
12 & Y1.12 & 0.604 & 0.2816 & Valid \\
\hline
\end{tabular}

Sumber: Hasil Olahan Data, 2019

Berdasarkan Tabel 1, Tabel 2, dan Tabel 3, maka dapat dilihat bahwa hasil uji validitas untuk setiap pernyataan mempunyai $r$ hitung $>\mathrm{r}$ tabel dangan taraf signifikan $\alpha=0,05$ dan nilai $r$ tabel sebesar 0,2816 , dapat disimpulkan bahwa semua pertanyaan pada variable motivasi kerja dinyatakan valid.

Tabel 4 Uji Reliabilitas

\begin{tabular}{|c|c|c|c|c|}
\hline No & Variabel & $\begin{array}{l}\text { Cronb } \\
\text { ach's } \\
\text { Alpha }\end{array}$ & $\begin{array}{l}\text { Cronba } \\
\text { ch's } \\
\text { Alpha } \\
\text { yang } \\
\text { harus } \\
\text { di } \\
\text { syaratk } \\
\text { an }\end{array}$ & Ket \\
\hline 1 & $\begin{array}{l}\text { Kompens } \\
\text { asi (X1) } \\
\text { Promosi }\end{array}$ & 0.762 & 0.6 & Reliabel \\
\hline 2 & $\begin{array}{l}\text { Jabatan } \\
\text { (X2) } \\
\text { Kinerja }\end{array}$ & 0.761 & 0.6 & Reliabel \\
\hline 4 & $\begin{array}{l}\text { Karyawa } \\
\mathrm{n}(\mathrm{Y})\end{array}$ & 0.761 & 0.6 & Reliabel \\
\hline
\end{tabular}

Pada Tabel 4 dapat dilihat bahwa $\mathrm{r}$ alpha dari masing-masing variable $\mathrm{X} 1, \mathrm{X} 2$, dan $\mathrm{Y}$ lebih besar dari 0,6 maka dengan demikian dapat disimpulkan data yang telah diuji dinyatakan reliabel.

\section{Hasil Penelitian}

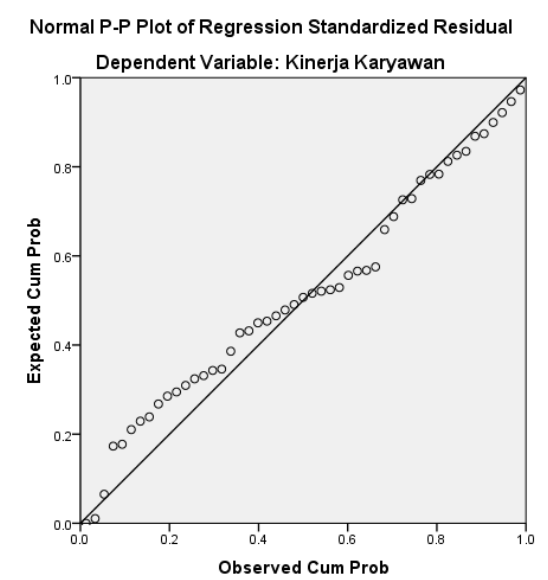

Gambar 1 Hasil Uji Grafik Normal P-P plot

Pada Gambar 1 di atas memperhatikan ketentuan bahwa titik-titik data menyebar di sekitar garis diagonal dan mengikuti arah garis diagonal maka dapat dikatakan data memenuhi asumsi normalitas.

Uji Multikolinearitas

Tabel 5 Hasil Uji Multikolinearitas

\begin{tabular}{|c|c|c|}
\hline \multicolumn{3}{|c|}{ Coefficents ${ }^{\text {a }}$} \\
\hline \multirow[t]{2}{*}{ Model } & \multicolumn{2}{|c|}{ Collinearity Statistics } \\
\hline & Tolerance & VIF \\
\hline 1 (constant) & & \\
\hline Kompensasi & 0,848 & 1,179 \\
\hline Promosi Jabatan & 0,882 & 1,133 \\
\hline
\end{tabular}

a.Dependent Variabel : Kinerja Karyawan

Sumber: Hasil pengolahan data, 2019

Berdasarkan Tabel 5 di atas menunjukkan bahwa nilai VIF untuk variabel Kompensasi, Promosi Jabatan masing-masing sebesar 1,179 dan 1,133sehingga dapat disimpulkan bahwa dalam model regresi tidak terdapat gejala multikolinearitas antar variabel bebas karena nilai VIF nya lebih kecil dari 10 yang berarti bahwa semua variabel tersebut dapat digunakan sebagai variabel yang saling independen. 


\section{Uji Heteroskedastisitas}

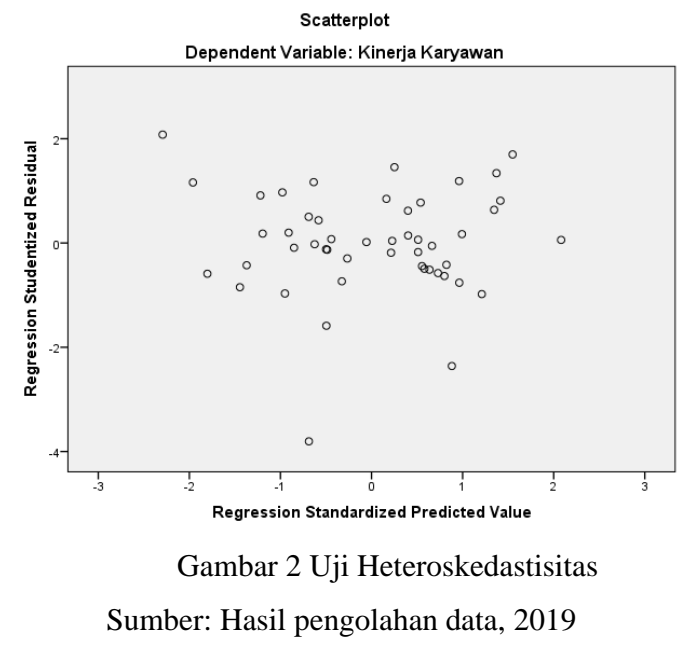

Pada Gambar 2 di atas dapat dilihat persebaran titik-titik yang acak di atas maupun di bawah angka 0 dari sumbu $\mathrm{Y}$, maka dapat disimpulkan dari gambar tersebut bahwa dalam model regresi tidak terjadi heteroskedastisitas.

\section{PENGUJIAN HIPOTESIS}

\section{Analisis Regresi Linear Berganda}

Berdasarkan hasil uji regresi linier berganda, dapat diperoleh persamaan sebagai berikut: $\mathrm{Y}=7,485+0,282+0,351 \mathrm{X} 2+\mathrm{e}$ penjelasan dari persamaan tersebut adalah:

1. Konstanta memiliki nilai sebesar 7,485 ini menunjukan jika Kompensasi (X1), Promosi Jabatan (X2) nilainya adalah nol, maka Kinerja Karyawan memiliki 7,485.

2. Variabel Kompensasi (X1) memiliki nilai koefisien regresi sebesar 0,282 hal ini berarti jika variabel independen lain nilainya tetap atau tidak berubah, maka setiap kenaikan 1 poin atau $1 \%$ variabel Kompensasi akan meningkatkan nilai Kinerja Karyawan sebesar 0,282.

3. Variabel Promosi Jabatan (X2) memiliki nilai koefisien regresi sebesar 0,351 hal ini berarti jika variabel independen lain nilainya tetap atau tidak berubah, maka setiap kenaikan 1 poin atau $1 \%$ variabel
Promosi Jabatan akan meningkatkan nilai Kinerja Karyawan sebesar 0,351. Koefisien variabel bernilai positif artinya terdapat hubungan positif antara Pelatihan (X2) dengan Kinerja Karyawan (Y), artinya semakin meningkat nilai Promosi Jabatan (X2) maka akan meningkatkan Kinerja Karyawan (Y).

\section{Analisis Uji t (Parsial)}

Variabel kompensasi (X1) nilai t hitung $2,530>\mathrm{t}$ tabel 1,679 dan nilai signifikannya $0,015>0,05$ yang berarti Ho diterima. Ho: Kompensasi berpengaruh terhadap kinerja karyawan. Ha: Kompensasi berpengaruh secara signifikan terhadap kinerja karyawan.

Variabel promosi jabatan (X2) nilai $t$ hitung $3,237>\mathrm{t}$ tabel 1,679 dan nilai signifikannya $0,002<0,05$ yang berarti Ho diterima. Ho: Promosi jabatan berpengaruh terhadap kinerja karyawan. Ha: Promosi jabatan berpengaruh tidak signifikan terhadap kinerja karyawan.

Variabel kinerja karyawan (Y) nilai f hitung $1,095<\mathrm{f}$ tabel 2,81 dan nilai signifikannya $0,370>0,05$ yang berarti Ho ditolak.

Ho: Kompensasi dan promosi jabatan secara simultan berpengaruh terhadap kinerja karyawan. Ha :Kompensasi, promosi jabatan, dan motivasi tidak berpengaruh secara simultan terhadap kinerja karyawan.

\section{Analisis Uji F (Simultan)}

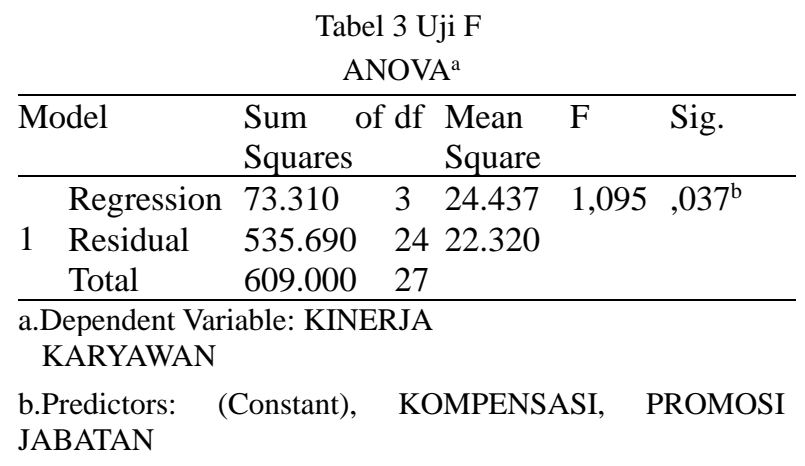


Sri Langgeng Ratnasari, Kinerja Karyawan:Kompensasi \& Promosi Jabatan...

Hasil uji $\mathrm{F}$ memperlihatkan nilai $\mathrm{F}$ sebesar 1,095 (F hitung) < 2,81 (F tabel) dan nilai probabilitas signifikansi sebesar $0,037<0,05$ sehingga keputusan yang diambil adalah Ho ditolak dan $\mathrm{Ha}$ diterima, artinya variabel Kompensasi dan Promosi Jabatan berpengaruh secara simultan terhadap variabel kinerja karyawan.

\section{HASIL DAN PEMBAHASAN}

Berdasarkan Rumusan Masalah, Tujuan Penelitian, Hipotesis, dan hasil pengujian statistik, diperoleh hasil sebagai berikut:

1. Kompensasi berpengaruh signifikan terhadap kinerja karyawan. Hasil penelitian ini mendukung hasil penelitian Armansyah, Idris, dan Putu (2018), Hendro (2018), Laminingrum (2016), Latief, Rizki, dan Mariana (2018), Maulana (2018), Pudjo (2018), Putra, Hasanuddin, dan Wirastuti (2018), Syaifullah (2018).

2. Promosi Jabatan berpengaruh signifikan terhadap kinerja karyawan. Hasil penelitian ini mendukung hasil penelitian Datu, Aldofina, Dotulong (2017), Maulana (2018), Prabowo, Al Musadieq, dan Ruhana (2016), dan Suparinah (2018).

3. Kompensasi dan Promosi Jabatan secara simultan berpengaruh signifikan terhadap kinerja karyawan. Hasil penelitian ini mendukung hasil penelitian Maulana (2018) dan Suparinah (2018).

\section{KESIMPULAN}

Berdasarkan hasil penelitian, maka dapat disimpulkan sebagai berikut:

1. Kompensasi berpengaruh signifikan terhadap kinerja karyawan.

2. Promosi Jabatan berpengaruh signifikan terhadap kinerja karyawan.
3. Kompensasi dan Promosi Jabatan berpengaruh secara simultan berpengaruh signifikan terhadap kinerja karyawan.

\section{DAFTAR PUSTAKA}

[1] Amalia Syarah, Fakhri Mahendra. (2016). Pengaruh Motivasi Kerja Terhadap Kinerja Karyawan Pada PT. Gramedia Asri Media Cabang Emerland Bintaro.Jurnal Computech \& Bisnis. ISSN 2442-4943, Vol 10, No 2, Desember 2016, 119-127 (Online) (Hal 121).

[2] Armansyah Andi, Azis Idris, Evvy RossantyNiluh Putu. (2018). Pengaruh Kompensasi Dan Disiplin Kerja Terhadap Kinerja Pegawai Kantor BPJS Kesehatan Cabang Palu.Jurnal Ilmu Manajemen Universitas Tadulako. ISSNOnline 2443-3578/ISSN Printed 2443-1850, Vol. 4, No. 3, September 2018, 235-244. (Online). (Hal. 238).

[3] Bangun, Wilson. 2015. Manajemen Sumber Daya Manusia. Jakarta: Erlangga.

[4] Datu Sabar Navrathin, Adolfina, Dotulong Lucky O.H. (2017). Pengaruh Promosi Jabatan Dan Mutasi Terhadap Kinerja Pegawai (Studi Pada Pegawai Kantor Wilayah Direktorat Jenderal Perbendaharaan Provinsi Sulawesi Utara). Jurnal EMBA, ISSN 2303-1174, Vol.5 No.2 Juni 2017, Hal. 404 - .413. (Online). (Hal. 405, 407).

[5] Dessler, Gary. 2015. Manajemen Sumber Daya Manusia. Edisi Kesepuluh. Jakarta Barat. PT Indeks.

[6] Fajar, Siti, dan Heru. 2016. Manajemen Sumber Daya Manusia. Edisi Kedua. Yogyakarta. UPP STIM YKPN.

[7] Fahmi, Irham. 2016. Manajemen Sumber Daya Manusia Teori Dan Aplikasi. Bandung: Alphabeta.

[8] Handoko, Hani T. 2016. Manajemen 
Personalia dan Sumber Daya Manusia. BPFE: Yogyakarta.

[9] Hasibuan, Malayu S.P. 2016. Manajemen Sumber Daya Manusia. Edisi Revisi. Jakarta: Penerbit PT. Bumi Aksara.

[10] Hendro Timoti. (2018). Pengaruh Kompensasi Dan Kepuasan Kerja Terhadap Kinerja Karyawan Tetap CV. Karya Gemilang. Jurnal AGORA Vol 6, No. 1, (2018). (Online). (Hal. 1-2).

[11] Laminingrum Anny Kusumo. (2016). Pengaruh Kompensasi Terhadap Motivasi Kerja Pada Karyawan Biro Pelayanan Sosial Dasar Di Sekretariat Daerah Provinsi Jawa Barat. Jurnal e-Proceeding of Management.ISSN: 2355-9357, Vol.3, No.2 Agustus 2016. (Online). (Hal. 1873).

[12] Latief Abdul, Rizqi ZatiMuhammad, Mariana Siti. (2018). Pengaruh Kompensasi Dan Motivasi Kerja Terhadap Kinerja Karyawan Pada Pusat Penelitian Kelapa Sawit (PPKS).Jurnal Sistem Informasi ISSN P: 2598-599X; E: 2599-0330.(Online). (Hal. 37-41).

[13] Leonardo, Edrick dan Fransisca A. 2015. Pengaruh Pemberian Kompensasi Nonfinansial Terhadap Kinerja Karyawan Pada PT. Kopanitia. AGORA Vol.3, No.2.

[14] MaulanaWahyu. (2018). Pengaruh Kepemimpinan, Kompensasi Dan Promosi Jabatan Terhadap Kinerja Karyawan Melalui Kepuasan Kerja Pada PT. Bank Jatim, Tbk Cabang Pamekasan. Makro, Jurnal Manajemen \& Kewirausahaan, ISSN 1412-2936, Vol. 3 No. 1 Mei 2018. (Online). (Hal 33)

[15] Mondy, R Wayne. 2015. Human Resource Management. Dialih bahasa oleh Bayu Airlangga. Edisi Kesepuluh. PT. Gelora Aksara Pratama.

[16] Prabowo Bastian, Al Musadieq Mochammad, Ruhana Ika. (2016).
Pengaruh Promosi Jabatan Terhadap Motivasi Kerja Dan Prestasi Kerja (Studi Pada Karyawan PT. Telkom Indonesia Witel Jatim Selatan Malang).Jurnal Administrasi Bisnis (JAB). Vol. 32 No. 1 Maret 2016. (Online). (Hal. 107).

[17] Pudjo Wibowo Fx. (2018). Pengaruh Kompensasi Dan Motivasi Terhadap Kinerja Karyawan (Studi Kasus PT Indoraya Internasional di Yogyakarta). SAINS: Jurnal Manajemen dan Bisnis p-ISSN: 1978-2241 e-ISSN:2541-1047 Volume X, Nomor 2, Juni 2018. (Online). (Hal. 178).

[18] Putra Udin, HasanuddinBakri, Wirastuti Wiri. (2018). Pengaruh Motivasi Kerja Dan Kompensasi Terhadap Kinerja Karyawan Pada PT. Balindo Manunggal Bersama Kota Palu.Jurnal Ilmu Manajemen Universitas Tadulako. ISSN Online 2443-3578/ISSN Printed 2443-1850, Vol. 4, No. 1, Januari 2018, 001-010. (Online). (Hal. 2-3)

[19] Sinambela, Lijan Poltak. 2015. Reformasi Pelayanan Publik. Jakarta: Bumi Aksara.

[20] Sudiro, Ahmad. 2015. Perencanaan Sumber Daya Manusia. Malang: UB Press.

[21] Sugiyono. 2016. Metode Penelitian Kuantitatif. Bandung: Alfabeta.

[22] Sunyoto, Danang. 2015. Manajemen Dan Pengembangan Sumber Daya Manusia. Yogyakarta: Center For Academic Publishing Service.

[23] Sutrisno, Edy. 2015. Manajemen Sumber Daya Manusia. Jakarta: Kencana.

[24] Wibowo. 2015. Manajemen Kinerja. Jakarta: Rajawali Pers.

[25] Suparinah Ela. (2018). Pengaruh Mutasi Dan Promosi Jabatan Terhadap Kinerja Karyawan Pada PT Waru Kaltim Plantation 
Sri Langgeng Ratnasari, Kinerja Karyawan:Kompensasi \& Promosi Jabatan...

Di Penajam Paser Utara. eJournal

Administrasi Bisnis, 2018, 6 (2): 425-438

ISSN

2355-5408,

ejournal.adbisnis.fisip-unmul.ac.id.

(Online). (Hal. 427).

[26] SyaifullahAs'ad, Adhi PrasetyoIwan. (2018). Pengaruh Kompensasi dan Motivasi Terhadap Kinerja Karyawan. Jurnal INOVASI. ISSN Print: 0216-7786 ISSN Online: 2528-1097(Hal. 4).

[27] Theodora Olivia. (2015). Pengaruh Motivasi Kerja Terhadap Kinerja Karyawan PT. Sejahtera Motor Gemilang. Jurnal AGORA. Vol. 3, No. 2, (2015). (Online) (Hal. 191). 